Bull. Chem. Soc. Ethiop. 2016, 30(2), 185-198.

Printed in Ethiopia

ISSN 1011-3924

DOI: http://dx.doi.org/10.4314/bcse.v30i2.3

(c) 2016 Chemical Society of Ethiopia

\title{
KINETIC AND EQUILIBRIUM STUDIES OF Pb(II) AND Cd(II) ADSORPTION ON AFRICAN WILD MANGO (IRVINGIA GABONENSIS) SHELL
}

\author{
Folahan Amoo Adekola*, Haleemat Iyabode Adegoke and Rukayat Abimbola Ajikanle \\ Department of Chemistry, University of Ilorin, P.M.B. 1515, Ilorin, Nigeria
}

(Received November 8, 2013; revised May 17, 2016)

\begin{abstract}
The adsorption behavior of $\mathrm{NaOH}$-activated African wild mango (Irvingia gabonensis) shell with respect to $\mathrm{Pb}^{2+}$ and $\mathrm{Cd}^{2+}$ has been studied in order to consider its application to purify metal finishing waste water. The optimum conditions of adsorption were determined by investigating the initial metal ions concentration, contact time, adsorbent dose, $\mathrm{pH}$ value of aqueous solution and temperature. The extent of adsorption of metal ions was investigated by batch method using metal concentrations in solution ranging from $5-200 \mathrm{mg} / \mathrm{L}$. The adsorption efficiencies were found to be $\mathrm{pH}$ dependent, with maximum metals uptake recorded at $\mathrm{pH}$ of 5 . The equilibrium adsorption capacity for lead and cadmium ions were obtained from Freundlich, Langmuir, Temkin and DRK isotherms and the experimental data were found to fit best the Langmuir isotherm with values of 21.28 and $40.00 \mathrm{mg} / \mathrm{g}$ for $\mathrm{Cd}(\mathrm{II})$ and $\mathrm{Pb}$ (II) ions, respectively. The Pseudo-second order kinetics model had the best fitting for lead and cadmium adsorption kinetic data. The thermodynamic investigation showed that the adsorption processes of both metals are exothermic. An optimum concentration of $0.05 \mathrm{M} \mathrm{HCl}$ was found to be adequate for the regeneration of the spent adsorbent with recovery values of $78 \%$ and $71 \%$ for $\mathrm{Pb}^{2+}$ and $\mathrm{Cd}^{2+}$ respectively from the spent adsorbent. The results revealed that lead and cadmium are considerably adsorbed on the adsorbent and could be an economic method for the removal of these metals from aqueous solutions.
\end{abstract}

KEY WORDS: Adsorption, Lead, Cadmium, Aqueous solution, African wild mango shell, Langmuir isotherm

\section{INTRODUCTION}

Many toxic heavy metals are being discharged into the environment as industrial wastes, causing serious soil and water pollution [1]. $\mathrm{Pb}^{2+}, \mathrm{Cu}^{2+}$ and $\mathrm{Cr}^{3+}$ are especially common metals that tend to accumulate in organisms, causing numerous diseases and disorder [2]. Numerous processes exist for removing dissolved heavy metals in aqueous solution and these include ion exchange, precipitation, phytoextraction, ultrafiltration, reverse osmosis and electro dialysis.

Lead has long been recognized as a highly toxic metal and poses a widespread threat to humans and wildlife [3]. Excessive lead exposure has been reported to result in brain damage and dysfunction of kidneys, liver, and central nervous system in humans, especially in children [4]. Lead contamination in the environment usually results from waste waters or effluents from lead mining, battery recycling, electronics assembly plants, and military facilities, as well as landfill leachate and urban rainwater runoff. Lead has recently been implicated in the death of over 400 children in Zamfara State in Nigeria; this resulted from the mining of lead-laden gold ore [5]. Cadmium has also been recognized for long as a highly toxic metal, which poses great concern to human health, cadmium's toxicity in certain forms and concentration causes a great deformity. The inhalation of fumes and vapours causes kidney damage, bronchitis, gastric and intestinal disorders, cancer, disorder of heart, liver and brain, renal dysfunction, anaemia, hypertension and bone marrow disorder [6].

Conventional cleanup technologies that are applied for $\mathrm{Pb}(\mathrm{II})$ and $\mathrm{Cd}(\mathrm{II})$ removal from contaminated water include chemical precipitation, solvent extraction, ion exchange, adsorption with activated carbon, oxidation and reduction, fixation or concentration. These methods are economically unfavourable or technically complicated, and are used only in special cases of wastewater treatment. Biosorption of heavy metals from aqueous solution is a relatively new

*Corresponding author. E-mail: fadekola@unilorin.edu.ng 
technology for the treatment of industrial wastewater. Adsorbent materials derived from low cost agricultural wastes can be used for the effective removal and recovery of heavy metal ions from wastewater streams. The major advantages of biosorption technology are its effectiveness in reducing the concentration of heavy metal ions to very low levels that are within the WHO maximum permissible limits, it's green chemistry nature and overall low operational cost [7]. Agricultural waste materials are considered to be economic and eco-friendly for heavy metal remediation due to their unique chemical composition, availability in abundance, renewability, low cost and greater efficiency [8]. Irvingia gabonensis shell is an agricultural waste material produced during the processing of Irvingia gabonensis seed. The shell which is an agricultural waste was employed in the removal of $\mathrm{Pb}$ (II) and $\mathrm{Cd}(\mathrm{II})$ ions from aqueous solution. The influence of initial metal concentration, temperature, $\mathrm{pH}$ and adsorbent dose were studied in order to obtain maximum adsorption capacity of the shell. This study has been undertaken with the aim of finding economic value for this category of wastes.

\section{EXPERIMENTAL}

\section{Sample collection and pre-treatment}

The seeds of Irvingia gabonensis shell used for this study were collected from some farm locations in Aramako-Ekiti, Ekiti State of Nigeria. The seeds were washed abundantly with water in order to remove impurities. The air-dried African mango shell was crushed with a manual blender to smaller particles followed by grinding and then sieved with $300 \mu \mathrm{m}$ sieve size. The powdered biomass was soaked in $2 \mathrm{~L}$ of $0.3 \mathrm{M} \mathrm{HNO}_{3}$ solution with occasional agitation for 24 hours. It was then filtered through a filter paper and washed with de-ionized water to neutrality and air-dried. The treatment of the adsorbent with $0.3 \mathrm{M} \mathrm{HNO}_{3}$ solution was expected to facilitate the removal of any debris or soluble bimolecules that may interact with metal ions during the sorption process.

\section{Chemical activation of the biomass}

Chemical activation was carried out using $0.1 \mathrm{M} \mathrm{NaOH}$ as the activating reagent. $100 \mathrm{~g}$ of the biomass was weighed and washed twice with $3 \mathrm{~L}$ of $0.1 \mathrm{M} \mathrm{HCl}$, followed by centrifugation at moderate speed and then washed to neutrality with de-ionized water. The biomass was thereafter treated with $1 \mathrm{~L}$ of $0.1 \mathrm{M} \mathrm{NaOH}$ for a period of approximately 24 hours. The suspension was centrifuged and the biomass was then washed thoroughly with de-ionized water and filtered. The washed biomass was finally air-dried.

\section{Characterization of the adsorbent}

The approximate surface area of the adsorbents was determined using the Sears' method [9]. The elemental composition ranging from trace to major elements was determined by X-ray fluorescence (XRF) technique. The FT-IR investigation of the adsorbent before and after sorption was also carried out.

\section{Batch adsorption studies}

Experiments were carried out by varying the initial adsorbate concentration, contact time, adsorbent dose, temperature and $\mathrm{pH}$ of solution. The batch adsorption experiments were conducted using $0.1 \mathrm{~g}$ of adsorbent with $20 \mathrm{~mL}$ of solutions containing heavy metal ions of desired concentrations in $50 \mathrm{~mL}$ plastic bottles. The bottles were shaken with the aid of a thermostated shaker for 7 hours and solutions containing heavy metals were filtered through 
Whatman filter paper No. 42. The concentration of metal ions in the initial and final solution was determined by atomic absorption spectrophotometer. The amount of cadmium and lead ions adsorbed, $\mathrm{q}_{\mathrm{e}}(\mathrm{mg} / \mathrm{g})$ was computed by difference.

\section{Investigation of adsorption isotherms}

The Langmuir, Freundlich, Temkin and Dubinin-Radushkevich (DRK) adsorption models were considered in this study. These isotherms relate the amount of solute adsorbed at equilibrium per unit weight of adsorbent, $Q_{e}(\mathrm{mg} / \mathrm{g})$, to the adsorbate concentration at equilibrium, $C_{e}(\mathrm{mg} / \mathrm{L})$. The Langmuir model represents one of the first theoretical treatments of non linear sorption and suggests that the uptake occurs on a homogenous surface by monolayer sorption without interaction between the adsorbed molecules. The linear form of the Langmuir adsorption isotherm is represented as:

$C_{\mathrm{e}} / Q_{\mathrm{e}}=1 / Q_{\max } b+C_{\mathrm{e}} / Q_{\max }$

where $C_{e}$ is the equilibrium concentration of adsorbate $(\mathrm{mg} / \mathrm{L})$ and $\mathrm{Q}_{\mathrm{e}}$ is the amount of metal adsorbed per gram of the adsorbent at equilibrium $(\mathrm{mg} / \mathrm{g})$. $\mathrm{Q}_{\max }(\mathrm{mg} / \mathrm{g})$ and $\mathrm{b}(\mathrm{L} / \mathrm{mg})$ are Langmuir constants related to adsorption capacity and rate of adsorption respectively. The values of $\mathrm{Q}_{\max }$ and $\mathrm{b}$ were calculated from the slope and intercept of the Langmuir plot of $\mathrm{C}_{\mathrm{e}}$ versus $\mathrm{Ce} / \mathrm{Q}_{\mathrm{e}}$. The essential characteristics of Langmuir isotherm can be expressed in terms of dimensionless constant separation factor for equilibrium parameter, $\mathrm{R}_{\mathrm{L}}$.

The Freundlich model can be applied for non-ideal sorption onto heterogenous surfaces involving multilayer sorption. The linearized Freundlich model isotherm was applied for the adsorption of $\mathrm{Pb}$ and $\mathrm{Cd}$ and is expressed as:

$\log Q_{\mathrm{e}}=1 / n \log C_{\mathrm{e}}+\log K_{\mathrm{f}}$

where, $\mathrm{K}_{\mathrm{f}}$ and $\mathrm{n}$ are the constants incorporating all factors affecting the adsorption process (adsorption capacity and intensity). Values of $\mathrm{K}_{\mathrm{f}}$ and $\mathrm{n}$ were calculated from the intercept and slope of the plot.

The Dubinin-Radushkevich (DRK) model was applied to the equilibrium data to determine if sorption had occurred by physical or chemical processes. The DRK adsorption isotherm is represented as:

$\ln q_{\mathrm{e}}=\ln X_{\mathrm{m}}-\beta \varepsilon^{2}$

where $\mathrm{X}_{\mathrm{m}}$ is the theoretical saturation capacity $(\mathrm{mg} / \mathrm{g})$ and $\varepsilon$ is a gas constant related to adsorption energy $\left(\mathrm{mol}^{2} \mathrm{~K} \mathrm{~J}^{-2}\right), \mathrm{R}$ is the gas constant $\left(\mathrm{kJ} \mathrm{mol}^{-1} \mathrm{~K}^{-1}\right)$ and $\mathrm{T}$ is the temperature $(\mathrm{K})$. The constant $\beta$ gives an ideal information about the mean free energy of adsorption per molecule of the adsorbate and can be calculated from the DRK isotherm constant $\varepsilon$ using:

$E=1 / \sqrt{ }-2 \beta$

This sorption energy is independent of the temperature but varies depending on the nature of the adsorbent and adsorbate. The Temkin isotherm was studied by plotting the quantity sorbed $\mathrm{Q}_{\mathrm{e}}$ against $\ln \mathrm{C}_{\mathrm{e}}$ and the constants were determined from the slope and intercept:

$q_{e}=B \ln A+B \ln C_{\mathrm{e}}$

B is the Temkin constant related to heat of sorption $(\mathrm{J} / \mathrm{mol})$. A is the Temkin isotherm constant $(1 / \mathrm{g})$. 
Adsorption kinetics

The kinetics of $\mathrm{Pb}(\mathrm{II})$ and $\mathrm{Cd}(\mathrm{II})$ interactions was tested with different models such as Lagergren pseudo-first order equation, pseudo-second order equation, Elovich equation, Intraparticle diffusion equation and liquid film diffusion model. Although, the Lagergren plots for $\mathrm{Pb}$ (II) and $\mathrm{Cd}(\mathrm{II})$ do not fulfil the essential condition of yielding the same $\mathrm{q}_{\mathrm{e}}$ values as given by the experiments.

In this study, the pseudo-first order and pseudo-second order models have been tested at different concentrations. The pseudo-first order model can be expressed as follows:

$\log \left(Q_{\mathrm{e}}-Q_{\mathrm{t}}\right)=\log Q_{\mathrm{e}}-k_{1} t / 2.3 .03$

where $\mathrm{Q}_{\mathrm{e}}(\mathrm{mg} / \mathrm{g})$ is the mass of metal adsorbed at any time $\mathrm{t}$ and $\mathrm{k}_{1}\left(\mathrm{~min}^{-1}\right)$ is the equilibrium rate constant of pseudo-first order adsorption. The values of $\mathrm{k}_{\mathrm{ad}}$ and $\mathrm{Q}_{\mathrm{e}}$ are determined from the slope and intercept of the plot of $\log \left(\mathrm{Q}_{\mathrm{e}}-\mathrm{Q}_{\mathrm{t}}\right)$ versus $\mathrm{t}$ respectively.

The pseudo-second order model is based on the assumption that biosorption follows a second order mechanism. The equation can be expressed as [11]:

$\frac{1}{q_{t}}=\frac{1}{k_{2} q_{e}^{2}}+\frac{1}{q_{e}} t$

where $k_{2}$ is the pseudo-second order rate constant $(\mathrm{g} / \mathrm{mg} / \mathrm{min})$. The value of $\mathrm{Q}_{\mathrm{e}}$ is determined from the slope of the plot of $t / q_{t}$ versus $t$.

\section{Thermodynamic study}

In this study, the adsorption studies were carried out between $30-55{ }^{\circ} \mathrm{C}$. The values of the thermodynamic parameters such as $\Delta \mathrm{G}^{0}, \Delta \mathrm{H}^{\circ}$, and $\Delta \mathrm{S}^{\circ}$, describing the metal uptake by the biomass were calculated using the thermodynamic equation described below:

$k_{\mathrm{d}}=q_{\mathrm{e}} / C_{\mathrm{e}}$

The plot of $\ln \mathrm{k}_{\mathrm{d}}$ versus $1 / \mathrm{T}$ gives a straight line with $\Delta \mathrm{H}^{\circ}$ and $\Delta \mathrm{S}^{\circ}$ being calculated from the slope and intercept, respectively.

$\ln k_{\mathrm{d}}=\Delta S / R-\Delta H / R T$

where $\Delta S^{0}$ is the entropy change $(\mathrm{J} / \mathrm{mol} / \mathrm{K}), \Delta \mathrm{H}^{0}$ is the enthalpy change $(\mathrm{kJ} / \mathrm{mol}), \Delta \mathrm{G}^{\mathrm{o}}$ is the standard Gibb's free energy change for the adsorption $(\mathrm{J} / \mathrm{mol}), \mathrm{R}$ is the universal gas constant $(8.314 \mathrm{~J} / \mathrm{mol} / \mathrm{k})$ while $\mathrm{T}$ is the temperature $(\mathrm{K})$. These values could be used to compute $\Delta \mathrm{G}^{0}$ from the Gibb's relation,

$\Delta G=\Delta H-T \Delta S$

Study of desorption

The evaluation of the possibilities of regeneration of the adsorbent was undertaken by carrying out batch desorption experiments by varying the concentration of $\mathrm{HCl}$ from 0.05 to $0.2 \mathrm{M}$. The desorption index which is the ratio of sorbed metal and aqueous metal before and after desorption was calculated for the two metals ions. This enables to determine the degree of the reversibility of the sorption process. 


\section{RESULTS AND DISCUSSION}

\section{Characterization results}

The physico-chemical properties of the $\mathrm{NaOH}$-activated African wild mango (AAM) are shown in Table 1 . The surface of the material is slightly basic and it has very low organic content.

Table 1. Physico-chemical properties of $\mathrm{NaOH}$-activated African wild mango.

\begin{tabular}{|l|l|}
\hline Properties & AAM \\
\hline Particle size & $<300 \mu \mathrm{m}$ \\
\hline \% Moisture content & 16.2 \\
\hline Bulk density $(\mathrm{g} / \mathrm{mL})$ & 0.38 \\
\hline$\%$ Loss of mass on ignition & 0.80 \\
\hline Surface area $\left(\mathrm{m}^{2} / \mathrm{g}\right)$ & 48.6 \\
\hline $\mathrm{pH}$ & 7.80 \\
\hline
\end{tabular}

\section{Effect of initial concentration}

The initial metal ion concentration greatly influenced the equilibrium metal uptake and adsorption yield as shown in Figure 1. An increase in initial concentration increased the amount of ions adsorbed $(\mathrm{mg} / \mathrm{g})$. When the initial $\mathrm{Pb}$ (II) and $\mathrm{Cd}$ (II) ions concentration was varied from 5 to $200 \mathrm{mg} / \mathrm{g}$, the adsorption capacity of Irvingia gabonensis increased from 1.0 to $39.07 \mathrm{mg} / \mathrm{g}$ and 0.932 to $20.06 \mathrm{mg} / \mathrm{g}$ for $\mathrm{Pb}$ and $\mathrm{Cd}$ ions, respectively. The increase in adsorption capacity of adsorbents with the increase in metal ion concentration is probably due to higher interaction between metal ions and adsorbent surface [13].

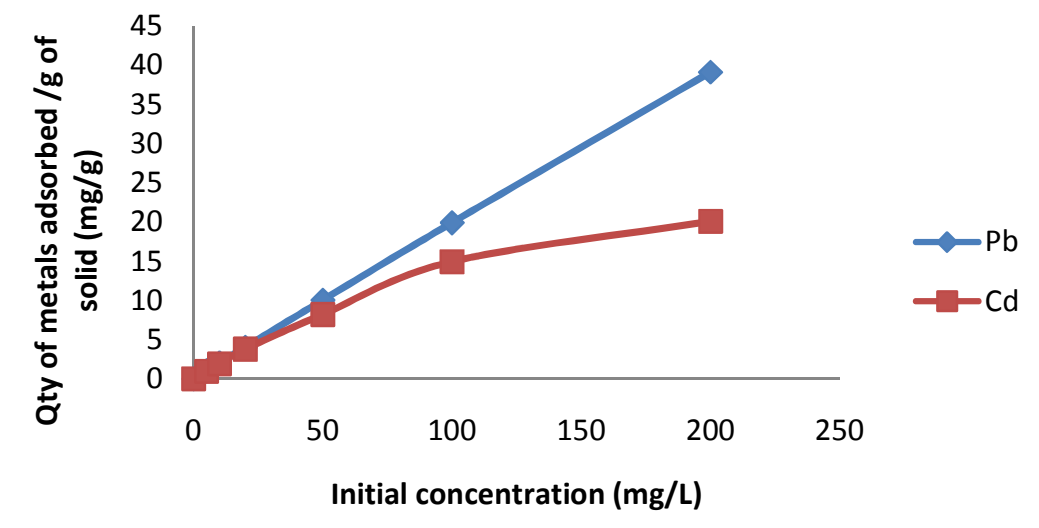

Figure 1. Variation of initial metal ions concentration on the sorption capacity of lead and cadmium ions: $\mathrm{m}=0.1 \mathrm{~g}, \mathrm{~V}=20 \mathrm{~mL}$, time $=7 \mathrm{~h}$, temperature $=30^{\circ} \mathrm{C}$.

Effect of contact time

It is very evident from the Figures $2 a-b$ that the process of adsorption which increases steadily within the first $15 \mathrm{~min}$ attains a constant value at $20 \mathrm{~min}$. The amount adsorbed per unit mass of the adsorbent showed consistent values from 30-120 min. Time of contact of the adsorbate and 
the adsorbent is of great importance in adsorption, because it depends on the nature of the system used. Metal ion adsorption reaches equilibrium within 5-15 min according to some researchers [14]. This has supported our observation of $\mathrm{Pb}(\mathrm{II})$ and $\mathrm{Cd}(\mathrm{II})$ capacity equilibrium where adsorption was achieved almost within $20 \mathrm{~min}$.

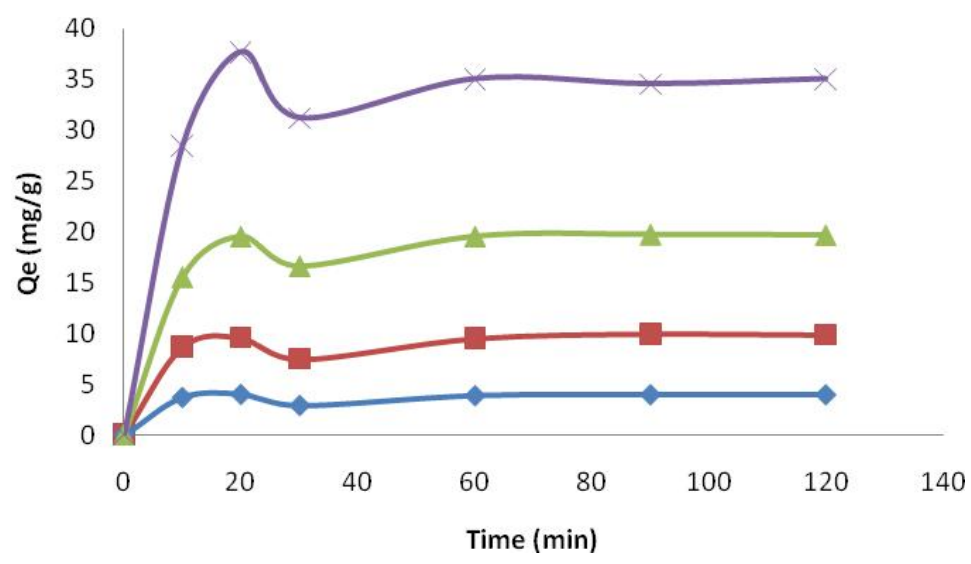

Figure 2a. Effect of contact time on the sorption of $\mathrm{Pb}^{2+}$ by $\mathrm{AAM}(\mathrm{m}=0.1 \mathrm{~g}, \mathrm{~V}=20 \mathrm{~mL}, \mathrm{pH}=$ 5 , temperature $=30{ }^{\circ} \mathrm{C}$, concentration $=20-200 \mathrm{mg} / \mathrm{L}$, blue $=20 \mathrm{mg} / \mathrm{L}$, red $=50$ $\mathrm{mg} / \mathrm{L}$, green $100 \mathrm{mg} / \mathrm{L}$, violet $=200 \mathrm{mg} / \mathrm{L} \mathrm{Pb}^{2+}$ ).

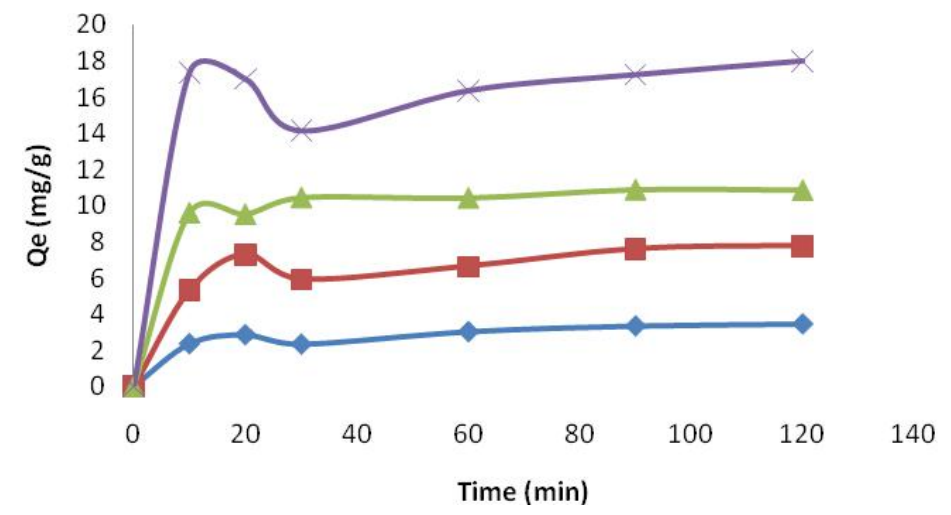

Figure 2b. Effect of contact time on the sorption of $\mathrm{Cd}^{2+}$ by $\mathrm{AAM}(\mathrm{m}=0.1 \mathrm{~g}, \mathrm{~V}=20 \mathrm{~mL}, \mathrm{pH}=$ 5 , temperature $=30{ }^{\circ} \mathrm{C}$, concentration $=20-200 \mathrm{mg} / \mathrm{L}$, blue $=20 \mathrm{mg} / \mathrm{L}$, red $=50$ $\mathrm{mg} / \mathrm{L}$, green $100 \mathrm{mg} / \mathrm{L}$, violet $=200 \mathrm{mg} / \mathrm{L} \mathrm{Cd}^{2+}$ ).

\section{Effect of adsorbent dose}

The influence of different amounts of adsorbent dose $(0.05-0.5 \mathrm{~g})$ on $\mathrm{Pb}$ (II) and $\mathrm{Cd}(\mathrm{II})$ ions adsorption at constant initial metal ion concentration of $200 \mathrm{mg} / \mathrm{L}$, equilibrium time (30 min) and temperature $303 \mathrm{~K}$, showed decrease in the quantity adsorbed with increase in adsorbent dose as shown in Figure 3. This can be attributed to the decrease in the number of sorbate ions 
concentration per active site available for sorption on the surface [15]. Increasing the mass of the adsorbent caused the sorptive capacity $\mathrm{q}_{\mathrm{e}}$, to be reduced. This effect has also been reported for the sorption of $\mathrm{Pb}(\mathrm{II})$ and $\mathrm{Cu}(\mathrm{II})$ on Sago waste [16]. It was also observed that the percentage removal of $\mathrm{Pb}(\mathrm{II})$ and $\mathrm{Cd}(\mathrm{II})$ increases with the increase in the adsorbent dose. The maximum percentage removal of $\mathrm{Pb}(\mathrm{II})$ and $\mathrm{Cd}(\mathrm{II})$ were $99 \%$ and $72 \%$, respectively, at $0.5 \mathrm{~g}$ of adsorbent dose and constant initial metal ions concentration of $200 \mathrm{mg} / \mathrm{L}$.

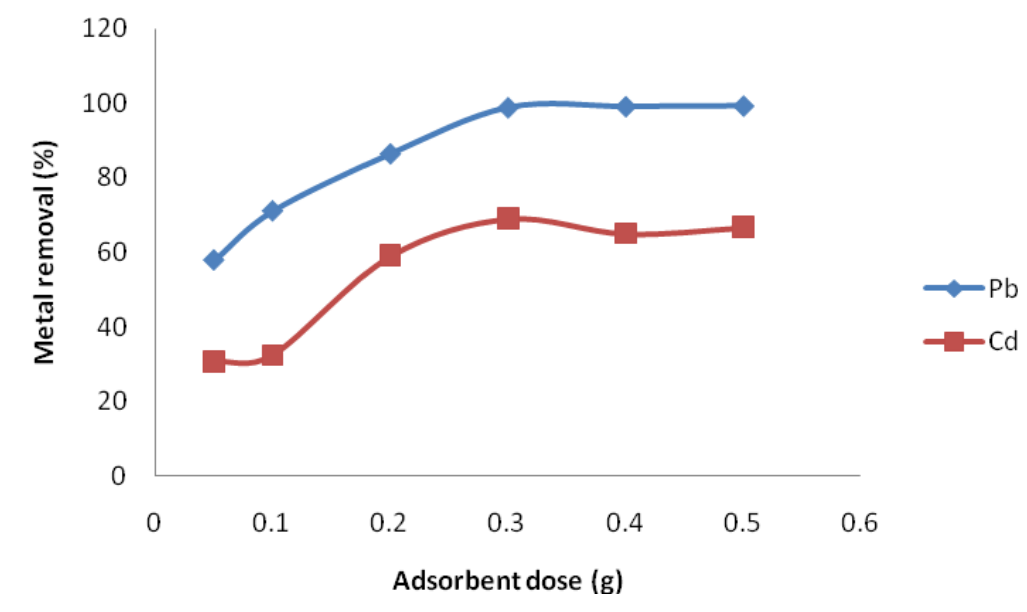

Figure 3. Effect of adsorbent dose on the percentage removal of $\mathrm{Pb}^{2+}$ and $\mathrm{Cd}^{2+}$ on $\mathrm{AAM}(\mathrm{m}=$ $0.1 \mathrm{~g}, \mathrm{~V}=20 \mathrm{~mL}, \mathrm{pH}=5$, temperature $=30{ }^{\circ} \mathrm{C}$, concentration $=200 \mathrm{mg} / \mathrm{L}$, time $=30$ $\min )$.

\section{Effect of temperature}

It is evident from Figure 4 that the adsorption capacity of $\mathrm{Pb}(\mathrm{II})$ and $\mathrm{Cd}(\mathrm{II})$ by the waste biomass decreased with increase in temperature from $30{ }^{\circ} \mathrm{C}$ to $45^{\circ} \mathrm{C}$. There is gradual decrease in the percentage removal from $82 \%$ to $71 \%$ for $\mathrm{Pb}$ (II) and $59 \%$ to $11 \%$ for $\mathrm{Cd}(\mathrm{II})$. The temperature higher than $45{ }^{\circ} \mathrm{C}$ might cause a change in the texture of the biomass and thus reduced its sorption capacity. However, subsequent increase in adsorption capacity was observed when temperature was raised beyond $45^{\circ} \mathrm{C}$ due to reduction in the volume of the metal ions concentration at high temperatures. An increase in the temperature resulted in a decrease in the amount of metal adsorbed per unit mass of the adsorbents, which showed that the reaction was exothermic in nature. At high temperature, the adsorbate-adsorbent complex became unstable and the metal ions escape from the solid phase to the bulk solution.

A decrease in the percentage removal of $\mathrm{Pb}$ (II) and $\mathrm{Cd}$ (II) ions with a rise in temperature supports the heterogenous nature of the $\mathrm{NaOH}$-activated African wild mango sample.

\section{Effect of $p H$}

The effect of $\mathrm{pH}$ on the adsorption of metal ions was carried out within the range that would not be influenced by the metal precipitation. The suitable $\mathrm{pH}$ range for $\mathrm{Cd}(\mathrm{II})$ and $\mathrm{Pb}(\mathrm{II})$ were found to be 2-6 [17]. The sorption capacity increased as the $\mathrm{pH}$ of the solution increases and reached a maximum value at $\mathrm{pH}$ of 6 as shown in Figure 5. Studies on heavy metal adsorption have shown that $\mathrm{pH}$ is one of the crucial parameters affecting the adsorption process [18]. There was 
increase in the quantity adsorbed per gram of adsorbent from $\mathrm{pH} 2$ to 5 for $\mathrm{Pb}(\mathrm{II})$ after which there was no gain in the adsorption capacity. A progressive increase was recorded up to $\mathrm{pH}$ of 4 for $\mathrm{Cd}(\mathrm{II})$ after which it reached a constant value. Maximum percentage removal for $\mathrm{Pb}(\mathrm{II})$ and Cd(II) was $77 \%$ and $67 \%$, respectively, at $\mathrm{pH}$ of 6 .

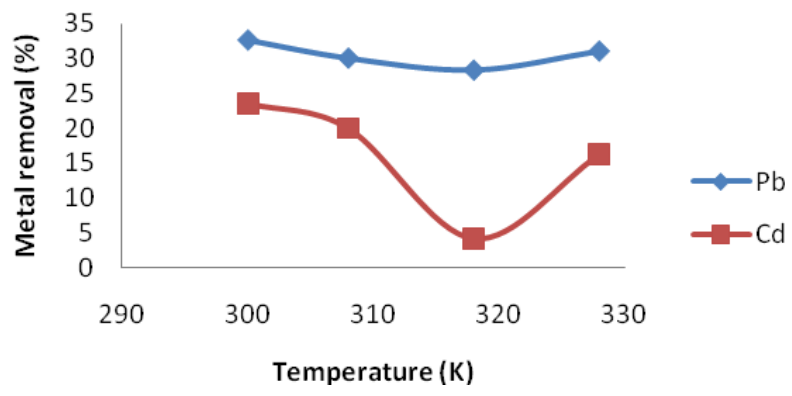

Figure 4. Effect of temperature on the percentage removal of $\mathrm{Pb}^{2+}$ and $\mathrm{Cd}^{2+}$ on $\mathrm{AAM}(\mathrm{m}=0.1 \mathrm{~g}$, $\mathrm{V}=20 \mathrm{~mL}, \mathrm{pH}=5$, temperature $=300-328 \mathrm{~K}$, concentration $=200 \mathrm{mg} / \mathrm{L}$, time $=30$ $\min )$.

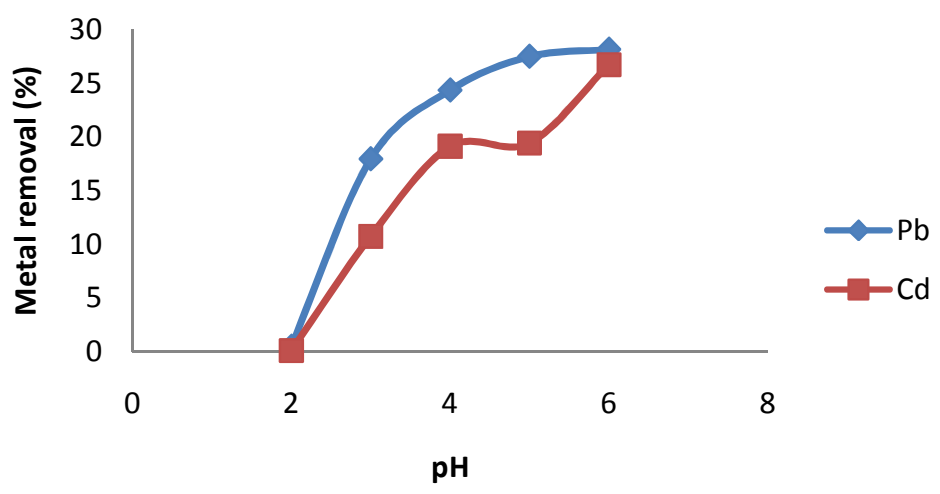

Figure 5. Effect of $\mathrm{pH}$ on the percentage removal of $\mathrm{Pb}^{2+}$ and $\mathrm{Cd}^{2+}$ on $\mathrm{AAM}(\mathrm{m}=0.1 \mathrm{~g}, \mathrm{~V}=20$ $\mathrm{mL}, \mathrm{pH}=2-6$, temperature $=30{ }^{\circ} \mathrm{C}$, concentration $=200 \mathrm{mg} / \mathrm{L}$, time $\left.=30 \mathrm{~min}\right)$.

In this work, an optimum $\mathrm{pH}$ was chosen to be 6 because precipitation of metal hydroxide has been previously reported at $\mathrm{pH}$ greater than 6 .

\section{Adsorption behavior of metals in binary solution}

The influence of the second metal ion in the mixtures on the single metal ion adsorption capacity increases as its concentration in the binary mixtures increases. As in the case of $\mathrm{Pb}^{2+} / \mathrm{Cd}^{2+}$, the $\mathrm{Pb}^{2+}$ adsorption capacity obtained for the single component $\left(\mathrm{Pb}^{2+}\right.$ only) decreases as the quantity of the $\mathrm{Cd}^{2+}$ in the initial binary mixture increases as shown in Table 2 and Figure 6. At $200 \mathrm{mg} / \mathrm{L}$ initial $\mathrm{Pb}$ (II) and $\mathrm{Cd}$ (II) ions concentration, the adsorbed metal quantities were found to be $30.22 \mathrm{mg} / \mathrm{g}$ and $18.32 \mathrm{mg} / \mathrm{g}$ for $\mathrm{Pb}(\mathrm{II})$ and $\mathrm{Cd}(\mathrm{II})$ ions, respectively. 
Similar result of adsorption pattern was observed for $\mathrm{Cd}(\mathrm{II}) / \mathrm{Pb}(\mathrm{II})$ binary solution system. The equilibrium uptake of $\mathrm{Cd}(\mathrm{II})$ increases with an increase in $\mathrm{Cd}(\mathrm{II})$ ion concentration. Without the presence of $\mathrm{Pb}$ (II) ion concentration in the solution, the equilibrium uptake was $18.3 \mathrm{mg} / \mathrm{g}$ at $200 \mathrm{mg} / \mathrm{L}$ initial $\mathrm{Cd}(\mathrm{II})$ ions concentration. It can be concluded that the presence of $\mathrm{Pb}$ (II) ion concentration in the binary solution influence the uptake of $\mathrm{Cd}(\mathrm{II})$ by AAM. The equilibrium capacity at various solutions is listed in the Table 2 .

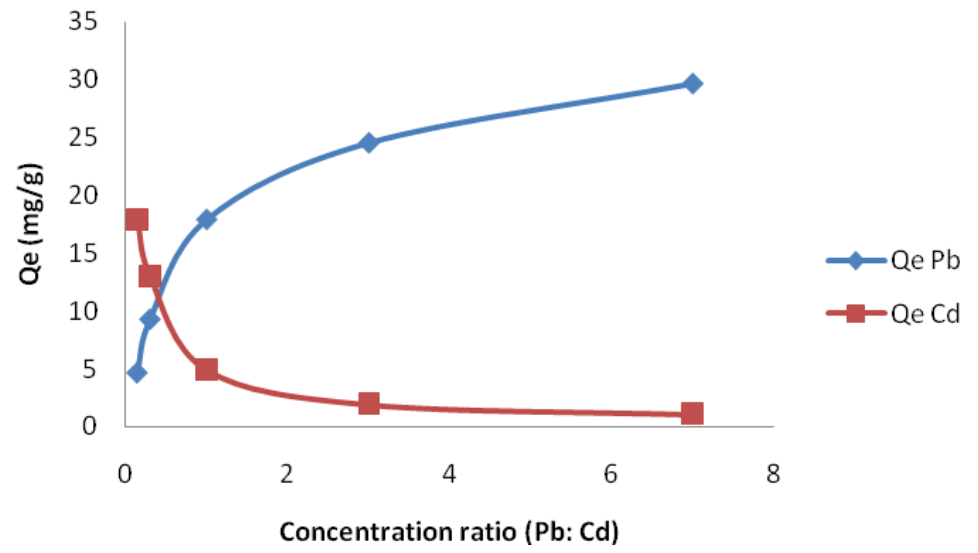

Figure 6. Plot of adsorption behavior of $\mathrm{Pb}(\mathrm{II})$ and $\mathrm{Cd}(\mathrm{II})$ ions in a binary solution $(\mathrm{m}=0.1 \mathrm{~g}, \mathrm{~V}$ $=20 \mathrm{~mL}$, temp. $=30^{\circ} \mathrm{C}, \mathrm{pH}=5$, contact time $=30 \mathrm{~min}$ ).

The overriding effect of the binary mixture of $\mathrm{Pb}(\mathrm{II})$ and $\mathrm{Cd}(\mathrm{II})$ seems to be antagonistic in this case. This is because the experimental equilibrium effect of the mixture is less than that of each of the components in the mixture.

Table 2. Adsorption capacities in binary system.

\begin{tabular}{|c|c|c|c|}
\hline Concentration (mg/L) & Concentration ratio of & \multicolumn{2}{|c|}{ Quantity adsorbed (mg/g) } \\
$\mathrm{Pb}(\mathrm{II})+\mathrm{Cd}(\mathrm{II})$ & $\mathrm{Pb}(\mathrm{II}): \mathrm{Cd}(\mathrm{II})$ & $\mathrm{Pb}(\mathrm{II})$ & 1.08 \\
\hline $175+25$ & 7.00 & 29.6 & 1.94 \\
\hline $150+50$ & 3.00 & 24.5 & 4.92 \\
\hline $100+100$ & 1.00 & 17.9 & 13.0 \\
\hline $50+150$ & 0.30 & 9.31 & 17.9 \\
\hline $25+175$ & 0.14 & 4.71 & \\
\hline
\end{tabular}

\section{Adsorption isotherms}

The results of experimental data were fitted with Langmuir, Freundlich Dubinin Radushkevich and Temkin isotherms and these were illustrated in Figures 7a-b. Better fitting of the experimental data to Langmuir isotherm with regression coefficient of 0.985 and 0.984 , respectively, indicate monolayer adsorption of $\mathrm{Pb}(\mathrm{II})$ and $\mathrm{Cd}(\mathrm{II})$. The Langmuir and Freundlich adsorption isotherms coefficients are summarized in Table 3. Langmuir isotherm parameter $\mathrm{q}_{\max }$ indicates higher maximum adsorption capacity for $\mathrm{Pb}(\mathrm{II})$ than $\mathrm{Cd}(\mathrm{II})$ ions on AAM. Langmuir equilibrium coefficient, $b$, showed stronger interaction between $\mathrm{Pb}$ (II) and $\mathrm{NaOH}$-activated African wild mango than for $\mathrm{Cd}(\mathrm{II})$. The large values of $\mathrm{b}$ for $\mathrm{Pb}$ (II) showed that the adsorption equilibrium is shifted towards the formation of the adsorbate-adsorbent complex. 


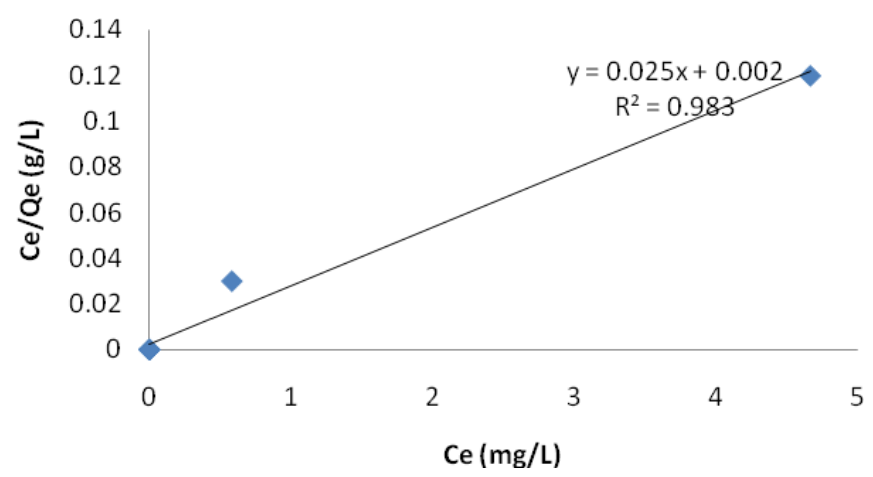

Figure 7a. Langmuir plot for sorption of $\mathrm{Pb}^{2+}$ ions on $\mathrm{AAM}$ at $\mathrm{pH}=5$, temp. $=30{ }^{\circ} \mathrm{C}$, adsorbent dose $=0.1 \mathrm{~g}$.

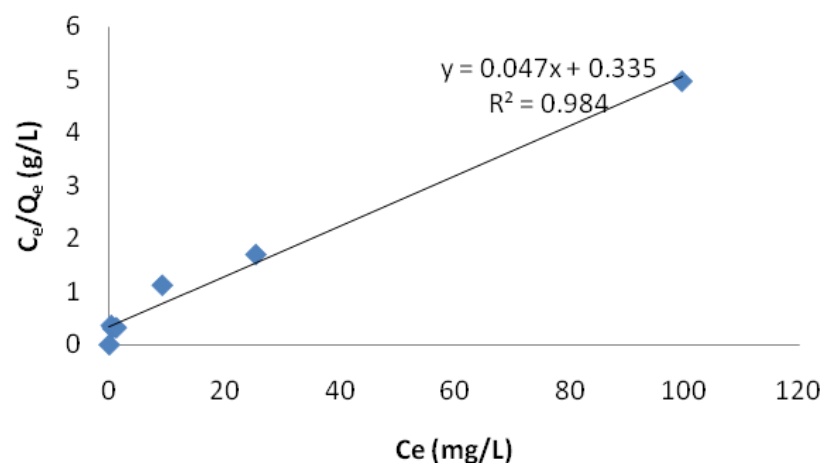

Figure 7b. Langmuir plot for sorption of $\mathrm{Cd}^{2+}$ ions on $\mathrm{AAM}$ at $\mathrm{pH}=5$, temp. $=30{ }^{\circ} \mathrm{C}$, adsorbent dose $=0.1 \mathrm{~g}$.

The Freundlich equation gives an adequate description of adsorption data over a restricted range of concentration and suggests heterogeneity of the adsorption sites on the biomass. This isotherm does not fit into the adsorption of $\mathrm{Pb}(\mathrm{II})$ on $\mathrm{AAM}$ but gives a moderate fitting for the adsorption of $\mathrm{Cd}(\mathrm{II})$ with regression coefficient of 0.876 . The Freundlich isotherm parameter $\mathrm{k}$ indicates adsorption intensity when concentration of metal ion in equilibrium is unitary. Values of $1 / \mathrm{n}$ less than 1 indicate favorable adsorption of the metals and the values of $\mathrm{n}$ within the range of 1-10 represent good adsorption. High values of $\mathrm{k}$ indicate high adsorption intensity. The sorption free energy, $E_{D}$ value calculated from the Dubinin-Radushkevich plot was $1.29 \mathrm{~kJ} / \mathrm{mol}$ and $-1.51 \mathrm{~kJ} / \mathrm{mol}$ for $\mathrm{Pb}(\mathrm{II})$ and $\mathrm{Cd}(\mathrm{II})$, respectively. $\mathrm{E}_{\mathrm{D}}$ value less than $8 \mathrm{~kJ} / \mathrm{mol}$ showed that the adsorption process of lead and cadmium on $\mathrm{NaOH}$-activated African mango follows physical adsorption. The theoretical saturation capacity, $X_{\mathrm{m}}$ values are 3.73 and $6.81 \mathrm{mg} / \mathrm{g}$ for $\mathrm{Pb}(\mathrm{II})$ and $\mathrm{Cd}(\mathrm{II})$, respectively. Other isotherms studied showed lower correlation coefficients as listed in Table 3. The Temkin isotherm constant, A was $1.774 \mathrm{~L} / \mathrm{g}$ and $2.214 \mathrm{~L} / \mathrm{g}$ for $\mathrm{Pb}$ (II) andCd (II), respectively. The heat of sorption, B was estimated to be $15.2 \mathrm{~J} / \mathrm{mol}$ and $3.5 \mathrm{~J} / \mathrm{mol}$ for $\mathrm{Pb}$ (II) and $\mathrm{Cd}(\mathrm{II})$, respectively. Good adsorption data fitting was however obtained for Temkin isotherm in respect of $\mathrm{Cd}(\mathrm{II})$. 
Table 3. Parameters for the adsorption isotherms.

\begin{tabular}{|c|c|c|c|c|c|c|c|c|c|c|c|c|c|c|c|}
\hline \multirow{2}{*}{$\begin{array}{c}\text { Metal } \\
\text { ion }\end{array}$} & \multicolumn{4}{|c|}{ Langmuir } & \multicolumn{4}{|c|}{ Freundlich } & \multicolumn{4}{|c|}{ DRK } & \multicolumn{3}{|c|}{ Temkin } \\
\hline & $\mathrm{q}_{\max }$ & $\mathrm{b}$ & $\mathrm{R}^{2}$ & $\mathrm{R}_{\mathrm{L}}$ & $1 / \mathrm{n}$ & $\mathrm{n}$ & $\mathrm{K}$ & $\mathrm{R}^{2}$ & $\mathrm{~B}$ & $\mathrm{X}_{\mathrm{m}}$ & $E_{D}$ & $\mathrm{R}^{2}$ & A & $\mathrm{B}$ & $\mathrm{R}^{2}$ \\
\hline $\mathrm{Pb}$ (II) & 40 & 12.5 & 0.985 & 0.004 & 0.97 & 1.03 & 4.22 & 0.186 & $-3 \times 10^{-7}$ & 3.73 & 1.29 & 0.207 & 1.774 & 15.2 & 0.479 \\
\hline $\mathrm{Cd}(\mathrm{II})$ & 21.28 & 0.14 & 0.984 & 0.035 & 0.64 & 1.57 & 1.52 & 0.876 & $2 \times 10^{-7}$ & 6.81 & -1.58 & 0.410 & 2.214 & 3.5 & 0.943 \\
\hline
\end{tabular}

Adsorption kinetics

The kinetics of $\mathrm{Pb}(\mathrm{II})$ and $\mathrm{Cd}(\mathrm{II})$ interactions was tested with different models such as Lagergren pseudo-first order equation, pseudo-second order equation, Elovich equation, Intraparticle diffusion equation and liquid film diffusion model. Although, the Lagergren plots for $\mathrm{Pb}$ (II) and $\mathrm{Cd}(\mathrm{II})$ as shown in Figures $8 \mathrm{a}$ and $8 \mathrm{~b}$ are linear, they do not fulfill the essential condition of yielding the same $\mathrm{q}_{\mathrm{e}}$ values as given by the experiments.

Table 4. Kinetic parameters for adsorption of $\mathrm{Pb}$ (II) and $\mathrm{Cd}(\mathrm{II})$ on $\mathrm{AAM}$.

\begin{tabular}{|c|c|c|c|c|c|c|c|}
\hline \multirow{2}{*}{$\begin{array}{c}\text { Metal } \\
\text { ions }\end{array}$} & \multirow{2}{*}{$\begin{array}{c}\text { Concent-ratio } \\
(\mathrm{mg} / \mathrm{L})\end{array}$} & \multicolumn{3}{|c|}{ Pseudo-first order } & \multicolumn{3}{|c|}{ Pseudo-second order } \\
\hline & & $\mathrm{q}_{\mathrm{e}}(\mathrm{cal})$ & $\mathrm{k}_{1}\left(\min ^{-1}\right)$ & $\mathrm{R}^{2}$ & $\mathrm{q}_{\mathrm{e}}(\mathrm{cal})$ & $\mathrm{k}_{2}\left(\mathrm{gmg}^{-1} \min ^{-1}\right)$ & $\mathrm{R}^{2}$ \\
\hline \multirow[t]{4}{*}{$\mathrm{Pb}(\mathrm{II})$} & 20 & 35.56 & $9.2 \times 10^{-5}$ & 0.137 & 4.072 & 0.0607 & 0.990 \\
\hline & 50 & 30.59 & $4.6 \times 10^{-4}$ & 0.380 & 10.26 & 0.0223 & 0.993 \\
\hline & 100 & 22.11 & $1.4 \times 10^{-3}$ & 0.447 & 20.33 & 0.0159 & 0.998 \\
\hline & 200 & 6.145 & $4.2 \times 10^{-3}$ & 0.107 & 35.46 & 0.0176 & 0.998 \\
\hline \multirow[t]{4}{*}{$\mathrm{Cd}(\mathrm{II})$} & 20 & 17.68 & $4.6 \times 10^{-4}$ & 0.802 & 3.701 & 0.0282 & 0.989 \\
\hline & 50 & 14.24 & $1.4 \times 10^{-3}$ & 0.590 & 8.117 & 0.0175 & 0.991 \\
\hline & 100 & 10.40 & $1.2 \times 10^{-3}$ & 0.767 & 11.11 & 0.0378 & 0.999 \\
\hline & 200 & 4.008 & $4.2 \times 10^{-3}$ & 0.242 & 18.18 & 0.0142 & 0.994 \\
\hline
\end{tabular}

The pseudo-second order kinetic model represented better the adsorption process compared to the pseudo-first order kinetic model as shown in Figures 8a-b. The pseudo-second order kinetic plots are of better linearity with correlation coefficient of 0.99 for all the concentrations determined. The calculated $\mathrm{q}_{\mathrm{e}}$ value from the pseudo-second order model is in good agreement with the experimental $\mathrm{q}_{\mathrm{e}}$ value. This suggests that the sorption followed the pseudo-second order model. The values of kinetic constants and $\mathrm{q}_{\mathrm{e}}$ values of $\mathrm{Pb}(\mathrm{II})$ and $\mathrm{Cd}(\mathrm{II})$ metal ions sorption onto adsorbent for both pseudo-first and pseudo-second order models at different concentrations studied are given in Table 4.

\section{Thermodynamics of the adsorption process}

The free energy change obtained for the adsorption of $\mathrm{Pb}(\mathrm{II})$ and $\mathrm{Cd}(\mathrm{II})$ at $300 \mathrm{~K}$, initial metal concentration of $200 \mathrm{mg} / \mathrm{L}$ and $\mathrm{pH} 5$ was $-303.6 \mathrm{kJmol}^{-1}$ and $-239.7 \mathrm{kJmol}^{-1}$ respectively. As shown in Figure 9, the decrease in value of the free energy with increase in temperature showed that the adsorption process is exothermic. With increase in temperature, the magnitude of Gibb's free energy decreases showing the exothermic nature of the adsorption.

The negative values of $\Delta \mathrm{H}$ and $\Delta \mathrm{S}$ (change in enthalpy and entropy) as shown in Table 5 suggest the exothermic and spontaneous nature of the sorption, respectively. The negative value of $\Delta \mathrm{G}$ confirmed the spontaneity of the adsorption process on Irvingia gabonensis shell.

Table 5. Thermodynamic constants of adsorption obtained for $\mathrm{Pb}(\mathrm{II})$ and $\mathrm{Cd}(\mathrm{II})$.

\begin{tabular}{|c|c|c|c|}
\hline Metal ions & $\Delta \mathrm{G}^{\mathrm{o}}(\mathrm{kJ} / \mathrm{mol})$ & $\Delta \mathrm{H}^{\mathrm{o}}(\mathrm{kJ} / \mathrm{mol})$ & $\Delta \mathrm{S}^{\mathrm{o}}(\mathrm{J} / \mathrm{mol} / \mathrm{K})$ \\
\hline $\mathrm{Pb}(\mathrm{II})$ & -303.6 & -275.6 & 93.34 \\
\hline $\mathrm{Cd}(\mathrm{II})$ & -239.7 & -118.7 & 403.6 \\
\hline
\end{tabular}

Bull. Chem. Soc. Ethiop. 2016, 30(2) 


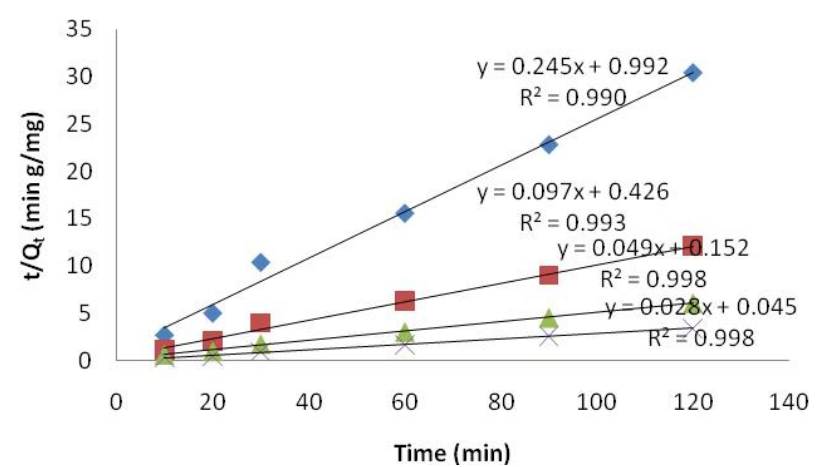

Figure 8a. Pseudo second order kinetics for sorption of $\mathrm{AAM}$ on $\mathrm{Pb}$ at $\mathrm{pH}=5$, temp. $=30{ }^{\circ} \mathrm{C}$, adsorbent dose $=0.1 \mathrm{~g}$.

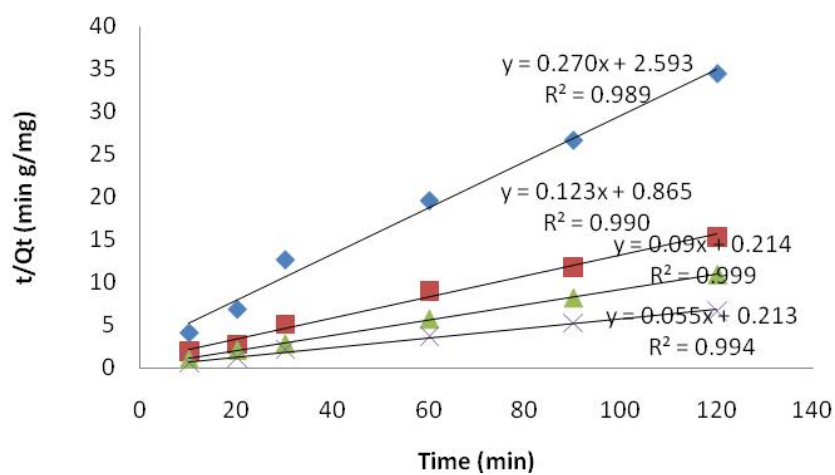

Figure 8b. Pseudo second order kinetics for sorption of AAM on $\mathrm{Cd}(\mathrm{II})$ at $\mathrm{pH}=5$, temp. $=30$ ${ }^{\circ} \mathrm{C}$, adsorbent dose $=0.1 \mathrm{~g}$.

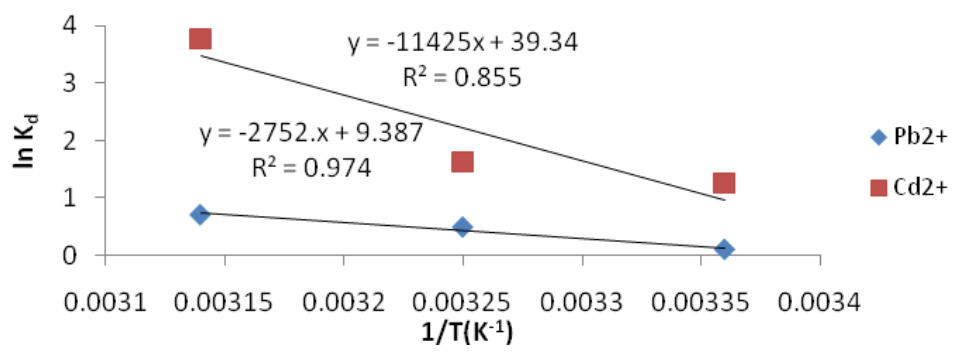

Figure 9. Thermodynamic plot of $\mathrm{Pb}(\mathrm{II})$ and $\mathrm{Cd}(\mathrm{II})$ ions on $\mathrm{AAM}$ at $200 \mathrm{mg} / \mathrm{L}$.

FT-IR spectra analysis

The FT-IR spectra of unloaded and metal loaded Irvingia gabonensis biomass in the range of $400-4000 \mathrm{~cm}^{-1}$ revealed complex nature of the adsorbent as evidenced by the presence of a large number of peaks. Table 6 showed the infrared adsorption wavenumber of each peak and corresponding functional groups of the adsorbent before and after adsorption of $\mathrm{Pb}$ (II) and $\mathrm{Cd}(\mathrm{II})$ ions. The absorption peak at $3792.18 \mathrm{~cm}^{-1}$ indicates the existence of free and 
intermolecular bonded hydroxyl group which was shifted to $3446.91 \mathrm{~cm}^{-1}$ and $3566.5 \mathrm{~cm}^{-1}$ after contact with $\mathrm{Pb}(\mathrm{II})$ and $\mathrm{Cd}(\mathrm{II})$, respectively, indicating participation of these functional groups in metal binding. Peak around $1737.99 \mathrm{~cm}^{-1}$ corresponds to the $\mathrm{C}=\mathrm{O}$ stretching that may be attributed to the aromatic groups and this was shifted to $1734.06 \mathrm{~cm}^{-1}$ after contact with $\mathrm{Pb}(\mathrm{II})$ and $\mathrm{Cd}(\mathrm{II})$, respectively, thus pointing to changes in aromatic groups after $\mathrm{Pb}(\mathrm{II})$ and $\mathrm{Cd}(\mathrm{II})$ loading. Peak around $1664.62 \mathrm{~cm}^{-1}$ corresponding to the $\mathrm{C}=\mathrm{N}$ stretching groups, was shifted to $1654.98 \mathrm{~cm}^{-1}$ and $1653.05 \mathrm{~cm}^{-1}$ after contact with $\mathrm{Pb}$ (II) and $\mathrm{Cd}(\mathrm{II})$ ions, respectively. Peak around $1512.24 \mathrm{~cm}^{-1}$ corresponding to the $\mathrm{N}-\mathrm{O}$ asymmetry stretch of nitro compound shifted to $1508.38 \mathrm{~cm}^{-1}$ when the adsorbent was loaded. Peak around $1377 \mathrm{~cm}^{-1}$ corresponds to the $\mathrm{C}-\mathrm{H}$ bending $\left(-\mathrm{CH}_{3}\right)$, and it was shifted to $1373.36 \mathrm{~cm}^{-1}$ thus pointing to changes in $\mathrm{C}-\mathrm{H}$ bending after $\mathrm{Pb}$ (II) and $\mathrm{Cd}(\mathrm{II})$ exposure. Additional peaks at lower wavenumbers confirmed the presence of lead and cadmium on the surface of the adsorbent.

Table 6. FT-IR Spectra of UAM, AAM, and AAM-Pb and Cd loaded adsorbent.

\begin{tabular}{|c|c|c|c|c|c|c|c|}
\hline \multirow{2}{*}{ Adsorbent } & \multicolumn{7}{|c|}{ Wavenumber $\left(\mathrm{cm}^{-1}\right)$} \\
\cline { 2 - 8 } & $\mathrm{O}-\mathrm{H}$ & $\mathrm{C} \equiv \mathrm{C}$ & $\mathrm{C}=\mathrm{O}$ & $\mathrm{C}=\mathrm{N}$ & $\mathrm{N}-\mathrm{O}$ & $-\mathrm{CH}_{3}$ & Bending vibrations \\
\hline UAM & 3792.18 & 2135.27 & 1737.9 & 1664.6 & 1512.24 & 1371.4 & $437.86-896.93$ \\
\hline AAM & 3416.05 & 2133.34 & - & 1664.6 & 1512.24 & 1377.2 & $451.36-896.93$ \\
\hline $\mathrm{Pb}(\mathrm{II})$ loaded & 3446.91 & 2135.27 & 1734.0 & 1654.9 & 1508.35 & 1373.3 & $418.57-896.93$ \\
\hline $\mathrm{Cd}(\mathrm{II})$ loaded & 3566.5 & 2135.27 & 1734.0 & 1653.0 & 1508.35 & 1373.3 & $437.86-896.93$ \\
\hline
\end{tabular}

Desorption results

Desorption studies were helpful to explore the possibilities of recycling the adsorbent. Table 7 revealed the percentage desorption of $\mathrm{Pb}$ (II) and $\mathrm{Cd}(\mathrm{II})$ by various concentrations of $\mathrm{HCl}$ ranging from $0.05-0.2 \mathrm{M}$ which serve as the desorbing agent were tested to remove the metal ions from the adsorbent. Maximum percent desorption of $\mathrm{Pb}(\mathrm{II})$ and $\mathrm{Cd}(\mathrm{II})$ of $78 \%$ and $71 \%$ were, respectively, achieved within $1 \mathrm{~h}$ for $\mathrm{HCl}$ concentration of $0.05 \mathrm{M}$ from $\mathrm{NaOH}$ activated Irvingia gabonensis, as shown in Figure 10. When $\mathrm{HCl}$ was used as desorption agent, the adsorbent surface was covered with $\mathrm{H}^{+}$ions while the coordination spheres of chelated $\mathrm{Pb}(\mathrm{II})$ and $\mathrm{Cd}(\mathrm{II})$ ions were disrupted. Thereafter, the metal ions could not compete with $\mathrm{H}^{+}$ions for exchange sites and subsequently heavy metals ions were released from the solid surface into the solution [19].

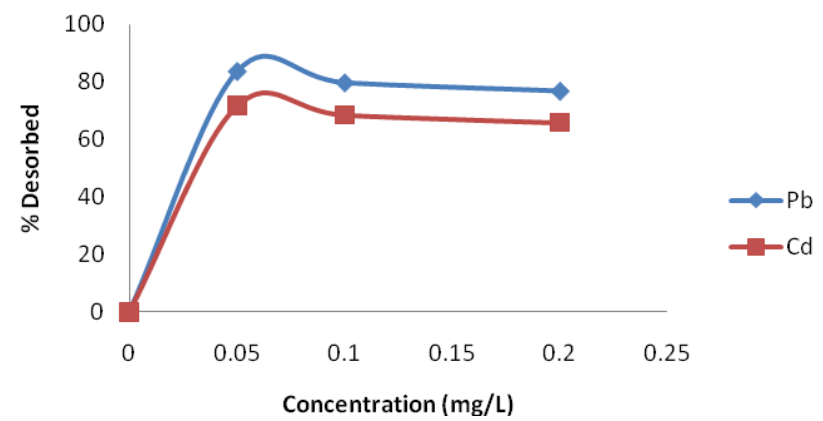

Figure 10. Desorption of $\mathrm{Pb}(\mathrm{II})$ and $\mathrm{Cd}(\mathrm{II})$ ions from the adsorbent by $0.05 \mathrm{M} \mathrm{HCl}$ (volume $=$ $20 \mathrm{~mL}$, adsorbent dose $=0.1 \mathrm{~g}$, contact time $=30 \mathrm{~min}$, and temp. $30^{\circ} \mathrm{C}$ ).

Desorption index

The desorption indices of $\mathrm{NaOH}$-activated African wild mango on $\mathrm{Pb}$ (II) and $\mathrm{Cd}$ (II) have been calculated and the values are summarized in Table 7 . The values of the desorption index (DI) 
were calculated for various concentrations of $\mathrm{HCl}$ from $0.05-0.2 \mathrm{M}$ in order to evaluate the degree of reversibility of $\mathrm{Pb}(\mathrm{II})-\mathrm{AAM}$ and $\mathrm{Cd}(\mathrm{II})-\mathrm{AAM}$ sorption process. A sorption process is considered to be completely reversible when DI equals 1 . The degree of irreversibility of a sorption reaction increases as DI value deviates from 1 [20]. In this study, the DI value for $\mathrm{Pb}$ (II)-AAM ranged from 1.254-1.277, while that of $\mathrm{Cd}$ (II)-AAM ranged from 0.711-0.728. The DI values are close to 1 which implies that the sorption process is practically reversible within the concentration range investigated.

Table 7. Values of \% desorbed and desorption indices (DI) of $\mathrm{Pb}(\mathrm{II})$ and $\mathrm{Cd}(\mathrm{II})$ by $\mathrm{HCl}$.

\begin{tabular}{|c|c|c|c|c|}
\hline \multirow{2}{*}{$\begin{array}{c}\text { Concentration of } \\
\mathrm{HCl}(\mathrm{M})\end{array}$} & \multicolumn{2}{|c|}{ \% Desorbed } & $\mathrm{2}$ Desorption index \\
\cline { 2 - 5 } & $\mathrm{Pb}(\mathrm{II})$ & $\mathrm{Cd}(\mathrm{II})$ & 1.25 & $\mathrm{Cd}(\mathrm{II})$ \\
\hline 0.05 & 77.9 & 70.5 & 1.26 & 0.711 \\
\hline 0.1 & 77.6 & 70.4 & 1.28 & 0.712 \\
\hline 0.2 & 76.5 & 68.9 & 0.728 \\
\hline
\end{tabular}

\section{CONCLUSION}

The results of our study revealed that $\mathrm{NaOH}$-activated African wild mango can be used for the removal of $\mathrm{Pb}(\mathrm{II})$ and $\mathrm{Cd}(\mathrm{II})$ ions from aqueous solution. Equilibrium adsorption studies showed that the system followed Langmuir model best. The kinetics studies revealed that the metal ions removal followed pseudo-second order rate equation. The interactions were thermodynamically favorable due to the exothermic nature of the process. Desorption experiment indicated that 0.05 $\mathrm{M} \mathrm{HCl}$ is adequate for the regeneration of the spent adsorbent.

\section{REFERENCES}

1. Lin, S.H.; Juang R.S. J. Hazard. Mater. 2002, 92, 315.

2. Inglezakis, V.J.; Loizidou, M.D.; Grigoropoulou, H.P. J. Colloid Interf. Sci. 2003, 261, 49.

3. Newland, L.W.; Daun, K.A. Handbook of Environmental Chemistry, Springer: New York; 1982; 3 , p 1.

4. World Health Organization Guidelines for Drinking-Water Quality, 3rd ed., World Health Organization: Geneva; 2006; p 54.

5. Debo, O. Guardian 2012, 3, 12.

6. Friberg, L.; Piscator, M.; Nordberg, G.F.; Kjellstrom, T. Cadmium in the Environment. 2nd ed., CRC Press: Cleveland, Ohio, USA; 1974.

7. Kratochvil, D.; Volesky, B. Trend Biotechnol. 1998, 16, 291.

8. Volesky, B.; Holan, Z.R. Biotechnol. Progress 1995, 1, 235.

9. Sears, G.W. Anal. Chem. 1956, 28, 1981.

10. Shawabkeh, R.A.; Tutunji, M.F. Appl. Clay Sci. 2003, 24, 111.

11. Ho, Y.S.; Wase, D.A.J.; Forster, C.F. Environ. Technol. 1996, 17, 71.

12. El-Said, A.G.; Badawy, N.A.; Garamon, S.E. J. Am. Sci. 2010, 6, 400.

13. Hanif, M.A.; Nadeem, R.; Bhatti, H.N.; Ahmad, N.R.; Ansari, T.M. J. Hazard. Mater. 2007, $139,345$.

14. Gadd, G.M.; De-Rome, L. Appl. Microbiol. Biotechnol. 1988, 29, 610.

15. Yu, B.; Zhang, Y.; Shukla, A.; Shukla, S.S.; Doris, K.L. J. Hazard. Mater. 2000, B80, 33.

16. Quek, S.Y.; Wase, D.A.J.; Forster, C.F. Water SA 1998, 24, 251.

17. Goksungur, Y.; Uren, S.; Guvenc, U. Bioresour. Technol. 2005, 96, 103.

18. Fourest, E.; Roux, J.C. Appl. Microb. Biotechnol. 1992, 37, 399.

19. Bansal, M.; Singh, D.; Garg, V.K.; Rose, P. Int. J. Civil Environ. Eng. 2009, 1, 108.

20. Adekola, F.A.; Abdus-salam, N.; Adegoke, H.I.; Adesola, A.M.; Adekeye, J.I.D. Bull. Chem. Soc. Ethiop. 2012, 26, 195. 